УДК 341.48 : 343.9 : (343.222.4 : 321)

\title{
РОЗВИТОК КОНЦЕПЦІї \\ КРИМІНАЛЬНОЇ ВІДПОВІДАЛЬНОСТІ ДЕРЖАВИ \\ У ПРАЦЯХ ПРОФЕСОРА ВОЛОДИМИРА АНТИПЕНКА: \\ НАУКОВИЙ ПОШУК У РАМКАХ НАУКОВОЇ ШКОЛИ МІЖНАРОДНОЇ КРИМІНОЛОГІЇ
}

\section{Важна Катерина Анатоліївна}

кандидат юридичних наук,

Київський національний університет культури і мистецтв,

м. Київ, Україна

ORCID: 0000-0001-5591-8853

kateryna.vazhna@gmail.com
Надіслано:

21.03.2021

Рецензовано:

30.03.2021

Прийнято:

15.04.2021

У статті розкривається внесок професора В. Ф. Антипенка у сучасний розвиток концепції кримінальної відповідальності держави (далі- КВД). Вказується, що науковець зробив вагомий внесок у сучасний розвиток концепції кримінальної відповідальності держави, доповнивши і «ожививши» дану концепцію новими науковими ідеями. Дослідження й подальший розвиток концепції КВД стали одним із векторів наукового пошуку у межах наукової школи міжнародної кримінології. Вказується, що В.Ф. Антипенко розробляв нові міжнародні нормативно-правові та інституційні механізми боротьби з міжнародними злочинами. Тому дослідження внеску професора В.Ф.Антипенка у розвиток концепції КВД $\epsilon$ важливим та може мати як теоретичне, так i важливе практичне значення у сфері протидії міжнародним злочинам та підтримання міжнародного миру та безпеки. Серед іншого, у статті розкривається позиція В.Ф.Антипенка щодо процесу трансформування волі індивідів у волю держави, а також щодо того, що інститут кримінальної відповідальності держави створює умови для недопущення невиправданого поширення санкцій (у межах реалізації міжнародно-правового примусу та у межах реалізації міжнародно-правової відповідальності держав за міжнародні злочини) на широке населення. На думку В.Ф.Антипенка, зміст кримінального покарання для індивідів, що генерують злочинні діяння держави і $є$ носіями відповідної приватної волі, полягає передусім у вилученні інструментів державного апарату, використання яких створює умови, з одного боку, для кримінальних в їх користь дій

(C)Важна К. А., 2021 


\section{Міжнародні відносини: теоретико-практичні аспекти \\ Випуск 7 (2021) \\ ISSN (print) 2616-745X; ISSN (online) 2616-7794}

держави, а з іншого, дозволяє переадресовувати авторство таких дій народу (суспільству). У результаті, як вказує вчений, головна ціль досягається, хоча й специфічним чином: кримінальне покарання держави і антикримінальна щодо неї превенція відбувається через позбавлення можливостей приватних осіб або корпоративних груп використовувати державний апарат у своїх корисливих цілях, надаючи поведінці держави злочинний характер.

Ключові слова: професор Володимир Федорович Антипенко; концепція кримінальної відповідальності держави; міжнародний злочин; міжнародне кримінальне право; міжнародна відповідальність; наукова школа міжнародної кримінології.

\section{Вступ}

Професор Володимир Федорович Антипенкоํㅜ здійснював свій науковий пошук у різних сферах міжнародного права. Переважно, вектори наукового пошуку В.Антипенка були пов'язані із дослідженням проблем боротьби 3 міжнародними злочинами та превенції міжнародних злочинів. Міжнародні злочини $\epsilon$ найтяжчими порушеннями міжнародного права, а боротьба 3 міжнародними злочинами та їх превенція продовжують залишатися актуальною проблемою. Вивчаючи та розвиваючи концепцію кримінальної відповідальності держави за вчинення міжнародних злочинів, В. Ф. Антипенко розробляв нові міжнародні нормативно-правові та інституційні механізми боротьби 3 міжнародними злочинами. Тому дослідження його внеску у розвиток концепції кримінальної відповідальності держави $є$ важливим та має як теоретичне, так і важливе практичне значення у сфері протидії міжнародним злочинам та підтримання міжнародного миру й безпеки.

\section{Аналіз останніх досліджень і публікацій}

Зміст ідей концепції кримінальної відповідальності держави за міжнародні злочини, а також можливості практичного втілення таких ідей досліджували зарубіжні вчені, зокрема: Р. Аго, М. Ш. Бассіоні, І. П. Бліщенко, Дж. Гінзбургс, Г. Доннедьє де Вабр, Ф. Малекян, В. Пелла, I. В. Фісенко та багато ін. фахівців. В українській доктрині вказану проблематику досліджували: В.Ф. Антипенко, К. А. Важна, В.А. Василенко, Н.А. Зелінська, I. І. Лукашук,

${ }^{1}$ Антипенко Володимир Федорович (23.01.1949 - 19.01.2017) - доктор юридичних наук, професор, завідувач кафедри міжнародного права (2008-2017) Навчально-наукового інституту міжнародних відносин Національного авіаційного університету (місто Київ, Україна) (Antypenko, 2013, p. 332; Vazhna and Voloshin, eds., 2018, pp. 1-9). 
Ю. В. Манійчук та ін. Також концепція кримінальної відповідальності державі $\epsilon$ одним із напрямів досліджень наукової школи міжнародної кримінології².

$$
\text { Щодо самого питання розвитку концепції кримінальної }
$$

відповідальності держави у працях професора Володимира Антипенка, то окремі аспекти цього питання досліджувалися у працях К. А. Важної (див., зокрема: Vazhna, 2017; Vazhna, 2013; Vazhna, 2019). Також роль внеску В. Ф. Антипенка у розвиток концепції кримінальної відповідальності держави обговорювалася у межах всеукраїнської науково-практичної конференції під «Наукові читання пам'яті професора Володимира Антипенка», яка відбулася у 2018 р. на базі кафедри міжнародного права Національного авіаційного університету (місто Київ, Україна) (Naukovi chytannya pamyati profesora Volodymyra Antypenka, 2018).

\section{Формулювання цілей статті}

Подальшого глибокого вивчення потребує зміст наукових ідей В.Ф. Антипенка щодо розвитку концепції кримінальної відповідальності держави; теоретичне значення внеску В.Ф.Антипенка у розвиток концепції кримінальної відповідальності держави; можливість практичної реалізації його ідей щодо кримінальної відповідальності держави у сучасному міжнародному праві.

Висвітлити внесок професора В.Ф.Антипенка у сучасний розвиток концепції кримінальної відповідальності держави. Окреслити й розкрити його ідеї у напрямі розробки й подальшого розвитку концепції кримінальної відповідальності держави.

\section{Виклад основного матеріалу дослідження}

У багатьох аспектах наукові погляди В. Ф. Антипенка випередили свій час. У своїх працях вчений насмілився піти значно далі прийнятих на той час стандартів у окремих сферах міжнародно-правового регулювання, заглянув за межі стандартного міжнародно-правового правового світогляду i стандартного міжнародно-правового мислення. В.Антипенко вмів виходити за рамки встановлених наукових поглядів, тим самим розширюючи ці рамки й одночасно збагачуючи, змістовно наповнюючи науку міжнародного права.

${ }^{2}$ Наукова школа міжнародної кримінології створена і розвивається на базі кафедри міжнародного права Навчально-наукового інституту міжнародних відносин Національного авіаційного університету (м. Київ, Україна). Наукову школу міжнародної кримінології започаткував доктор юридичних наук, професор В. Ф. Антипенко (Antypenko, 2013, pp. 332-339).

(C)Важна К. А., 2021 


\section{Міжнародні відносини: теоретико-практичні аспекти Випуск 7 (2021) ISSN (print) 2616-745X; ISSN (online) 2616-7794}

Наукові ідеї В. Антипенка у сфері міжнародного права були сміливими і часто кардинально новими. Широкий світогляд, досвід практичної роботи, уміння мислити нестандартно допомагали вченому здійснювати науковий пошук за межами наявного, часто неефективного міжнародно-правового інструментарію. У багатьох аспектах його наукові ідеї можуть стати основою для подальшого наукового пошуку із розв'язання актуальних сучасних міжнародно-правових проблем.

В. Антипенко $є$ автором багатьох наукових праць, які, будучи присвячені різній тематиці (у сфері міжнародного права), одночасно є взаємопов'язаними і взаємодоповнюють одна одну. Навколо наукових ідей та поглядів В. Антипенка на базі кафедри міжнародного права Національного авіаційного університету (Київ, Україна) сформувалася і розвивається наукова школа міжнародної кримінології (далі - наукова школа), засновником якої $\epsilon$ В.Ф. Антипенко. Вектори наукового пошуку В.Антипенка лягли в основу головних напрямів розвитку наукової школи.

Одним із векторів наукового пошуку наукової школи міжнародної кримінології $\epsilon$ дослідження й подальший розвиток концепції кримінальної відповідальності держави (далі- КВД). Ідеї й аргументація, викладені В. Антипенком у межах дослідження та подальшого розвитку концепції КВД, у багатьох аспектах пов'язані і грунтуються на його попередніх дослідженнях у інших актуальних сферах міжнародного права, зокрема, сфері протидії міжнародним злочинам і тероризму3, сфері розвитку науки міжнародної кримінології тощо.

В. Антипенко шукав нові шляхи підвищення ефективності міжнародного права у боротьбі з міжнародними злочинами. Із цією метою вчений звернувся до поширеної у певний час, проте дещо забутої в подальшому (принаймні на пострадянському просторі ${ }^{4}$ ) концепції кримінальної відповідальності держави.

Концепція кримінальної відповідальності держави не $є$ новою у науці міжнародного права. Вона розроблялася, вивчалася і розвивалася багатьма вченими - представниками різних націй і держав (Vazhna, 2017, pp.11-58). В.Антипенко зробив вагомий внесок у сучасний розвиток даної концепції,

3 У своїх працях В. Антипенко аргументував, що тероризм слід віднести до категорії міжнародних злочинів; у своїх працях вчений дав авторське визначення терміна «тероризм» (Antypenko, 2007, p. 279, 283-285; Vazhna, 2017, p. 168-170).

4 У радянській науці міжнародного права та міжнародно-правовій доктрині пострадянського простору концепція КВД часто супроводжувалася запереченнями i різкою критикою. 
доповнивши і «ожививши» їі новими науковими ідеями (зважаючи на сучасні реалії розвитку міжнародних взаємодій).

Прихильники концепції кримінальної відповідальності держави вказують, що в багатьох випадках міжнародні злочини вчиняє сама держава (адже такі міжнародні злочини як агресія, геноцид, апартеїд та ін. неможливо реалізувати без залучення практично всього державного механізму, включаючи державні фінансові ресурси), а значить - держава (як суб'єкт міжнародного права) повинна нести відповідальність за такі злочини. На думку розробників концепції КВД, відповідальність держави за міжнародні злочини повинна відрізнятися і бути тяжчою, ніж відповідальність за ординарні міжнародні правопорушення (делікти). Якщо мова йде про відповідальність за злочин (англ.- crime) як вид правопорушення, то і сам режим відповідальності держави за міжнародні злочини вчені окреслили терміном «кримінальна». Прихильники концепції КВД висували різні ідеї, обгрунтовували різні твердження і теорії щодо того яким має бути режим судочинства, відповідальності та якими мають бути покарання для застосування до держави за вчинення міжнародних злочинів.

Основоположником концепції кримінальної відповідальності держави справедливо вважають видатного румунського юриста-міжнародника Веспасіана В. Пеллу. У 1925 р. вийшла праця вченого «Колективна злочинність держав і кримінальне право майбутнього», у якій В. Пелла викладає цілісну концепцію кримінальної відповідальності держави. Він $\epsilon$ дуже відомим і непересічним вченим. Багато років він був Президентом Міжнародної асоціації 3 кримінального права. Для уможливлення в майбутньому реалізації кримінальної відповідальності держави, за рекомендацією Міжнародної асоціації з кримінального права В. Пелла розробив проєкти міжнародного кримінального кодексу та статуту міжнародного кримінального суду, які були предметом розгляду органів Ліги Націй та Організації Об’єднаних Націй (зокрема, Комісії міжнародного права) (Vazhna, 2017, p. 7-8, 76).

Серед розробників та прихильників концепції кримінальної відповідальності держави необхідно передусім також назвати французького юриста, члена Міжнародної асоціації 3 кримінального права, суддю Нюрнберзького воєнного Трибуналу від Франції, професора Генрі Доннедьє де Вабра. Із метою впровадження і реалізації кримінальної відповідальності держави вчений розробляв проєкти статуту міжнародного кримінального суду для держав та інші документи. Зокрема, у процесі обговорення та прийняття

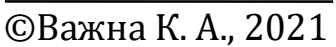




\section{Міжнародні відносини: теоретико-практичні аспекти \\ Випуск 7 (2021) \\ ISSN (print) 2616-745X; ISSN (online) 2616-7794}

Конвенції про попередження злочину геноциду i покарання за нього піднімалося питання про створення міжнародного кримінального суду для держав та розглядався проєкт статуту суду, у розробці якого брали участь В. Пелла та Г. Доннедьє де Вабр, а у Резолюції ГА ООН, якою було прийнято текст Конвенції про геноцид 1948 р., Комісії міжнародного права ООН було рекомендовано розглянути питання про можливість створення такого суду (Vazhna, 2017, p. 7-8, 78-80, 228).

Розробник та прихильник концепції кримінальної відповідальності держави вчений Фархад Малекян захистив у 1985 р. у Стокгольмському Університеті докторську дисертацію з питання кримінальної відповідальності держави (Vazhna, 2017, p.7-8, 83). Серед інших розробників і прихильників концепції КВД варто назвати спеціальних доповідачів Комісії міжнародного права ООН з теми відповідальності держави Роберто Аго, Рікардо Дж. Альфаро, Еміля Сендстрема (Vazhna, 2017, p. 11, 81, 82), а також видатних вчених: А. Бустаманте, Ф. В. Гарсіа Амадора, Дж. Гінзбургса, Ж. Дюма, П. Каржо, Г. Кельзена, Х. Лаутерпахта, Л. Ле-Фюра, А. Сальданья та ін. (Vazhna, 2017, pp. 7-8)

В. Ф. Антипенко почав досліджувати концепцію кримінальної відповідальності держави ще до 2007 р. Ці дослідження відобразилися, зокрема, у таких монографіях вченого: «Теорії світового розвитку і антитерористичне право. Логіка співставності» (2007) (Antypenko, 2007), «Антитерористична система держави» (2009) (Antypenko, 2009), «Міжнародна кримінологія: досвід дослідження тероризму» (2012) (Antypenko, 2012). Пізніше, у межах наукової школи міжнародної кримінологї, концепція КВД досліджувалася y кандидатській дисертації під назвою «Концепція кримінальної відповідальності держави», яка була написана під науковим керівництвом B. Антипенка та захищена у 2013 р. (Vazhna, 2013), а також у двох монографічних дослідженнях, автором одного 3 яких був В. Антипенко (Antypenko, 2016; Antypenko, 2016a; Vazhna, 2017).

Монографія В.Ф.Антипенка «Теорія кримінальної відповідальності держави» вийшла друком в українському (Antypenko, 2016) та німецькому (Antypenko, 2016а) видавництвах у 2016 p. і стала одним 3 найновіших досліджень у сфері відповідальності держави за міжнародні злочини, а також вагомим внеском у розвиток концепції кримінальної відповідальності держави. 
В. Антипенко зазначав, що значна «роль» держави (як основного гравця на міжнародній арені) у продукуванні сучасних елементів міжнародної криміногенності, перетворює ії на центральну «особистість» для кримінології міжнародної сфери. Отже, на думку вченого, у сучасних умовах інтенсивних глобалізаційних процесів (з їх криміногенністю) по-новому постає актуальність питання про міжнародну кримінальну відповідальність держави, яка вчинила злочин за міжнародним правом (Antypenko, 2012, p. 37; Vazhna, 2013, p. 27).

На прикладі відповідальності за вчинення тероризму В. Антипенко обгрунтовував доцільність і можливість режиму відповідальності держави, який за своїм характером повинен відрізнятися від режиму відповідальності за ординарні порушення міжнародного права (Antypenko, 2007, pp.330-340, 356, 361-367; Antypenko, 2012, pp. 215-224). В. Антипенко розробив підходи до правової кваліфікації тероризму, в межах яких обгрунтував можливість та доцільність застосування категорій вини і умислу до державиправопорушниці (Vazhna, 2017, p. 84-86). На думку В. Антипенка, тероризм $\epsilon$ одним 3 найяскравіших прикладів того, що не лише індивіди, а й держави повинні нести відповідальність з ознаками кримінальної за міжнародні злочини (Antypenko, 2007, p. 274; Antypenko, 2009, pp. 29-30).

Професор В.Антипенко доводив, що теорія кримінальної відповідальності держави В. Пелли знайшла актуальність стосовно сучасного тероризму. В.Антипенко вважав, що ідея кримінальної відповідальності держави за тероризм концептуально життєздатна, а головною ії метою слід вважати обгрунтування спеціального режиму відповідальності держав за тероризм (Antypenko, 2007, p. 359, 362; Vazhna, 2017, pp. 177-178).

Ще у 2007 р. у своїй праці В.Антипенко описав модель спеціального міжнародного кримінального суду з компетенцію виносити рішення щодо відповідальності держав за злочин тероризму (Antypenko, 2007, pp. 274-316, 366-367; Vazhna, 2017, pp. 84-86). Такий суд, на думку дослідника, повинен відповідати певним вимогам: бути наднаціональним; його функції повинні базуватися на можливості застосування насильницького примусу; рішення суду повинні бути інтернаціональними; діяльність вказаного суду хоча i не виключає згоди сторони спору з юрисдикцією суду, але, повинна бути незалежна від такої згоди. Вказаний суд, на думку В. Антипенка, повинен призначати заходи, які $\epsilon$ кримінальними, репресивними, спрямованими не тільки і не стільки на відшкодування збитку (у минуле), скільки

$\overline{\text { (CВажна К. А., } 2021}$ 


\section{Міжнародні відносини: теоретико-практичні аспекти \\ Випуск 7 (2021) \\ ISSN (print) 2616-745X; ISSN (online) 2616-7794}

на попередження схожих діянь у майбутньому за допомогою створення умов фізичної неможливості діяти таким чином або за допомогою цілеспрямованої зміни суб'єкта злочину (Antypenko, 2007, pp. 366-367). Міжнародний кримінальний суд із тероризму, на думку В. Антипенка, повинен створюватися на постійній основі. Також вказаний суд 3 тероризму повинен мати перспективи диференціації (Antypenko, 2007, p. 368, 369). Основу реалізації ідеї створення міжнародного кримінального суду з тероризму повинна становити кодифікація злочинів тероризму на базі його ретельної типологізації (Antypenko, 2007, p. 366; Vazhna, 2017, p. 178-179).

Більшість прихильників концепції КВД наголошували на тому, що у демократичних державах особовий склад центральних органів влади, як і політичний курс держави, формує населення держави, зокрема, шляхом участі у виборах. Тому В. Пелла, як і багато інших прихильників КВД вказували, що відповідальність повинна поширюватися на всю державу, а значить і на все населення. Ситуація, за якої негативні наслідки відповідальності держави відчуватиме все населення, на думку деяких учених, має привести до того, що населення заставить своїх лідерів припинити злочинну політику. В. Пелла вказував, що держава втілює групову волю нації, а якщо така воля $є$ злочинною, то покарання накладається на державу, і відповідно, на націю (Vazhna, 2017, p. 71).

В. Антипенко виступив проти такої позиції. На думку вченого, інститут «загальної волі» народу $\epsilon$ юридично неспроможним (Antypenko, 2012, pp. 186-196). У монографії під назвою «Теорія кримінальної відповідальності держави» В. Антипенко багато уваги приділив дослідженню категорій «воля», «умисел», «вина» держави. Важливим результатом дослідження, який поза сумнівом заслуговує уваги, стало розкриття i обгрунтування процесу трансформування волі індивідів у волю держави. В.Антипенко зазначав, що особливо актуальним $\epsilon$ інститут КВД щодо держав, де інтереси приватного бізнесу мають слабкий зв'язок із суспільним розвитком, а дії державної влади, у т. ч. в її вищих ланках, і державна політика відкрито обумовлені приватними інтересами, найчастіше інтересами приватного бізнесу. Уся діяльність держави, на думку В.Антипенка, «перенацілюється 3 загальнонародних потреб на корпоративні, що, як правило, супроводжується (або обумовлюється) кримінальною трансформацією відповідних державних механізмів» (Antypenko, 2016a, p. 99, 104).

В. Антипенко вважав, що у системі сучасного світоустрою держава виражає інтереси передусім панівного класу і часто воля держави навіть 
у демократичних країнах зводиться до волі правлячої верхівки. Основоположним серед групи внутрішніх факторів, що впливають на злочини, вчинені державою, на думку вченого, $є$ інтереси великого капіталу, які багато в чому визначають поведінку держави у міжнародному просторі. Отже, як зазначав В.Антипенко, відповідальність індивідів у комплексі відповідальності держави слід пов'язувати не лише 3 кримінальною за міжнародним правом відповідальністю посадовців, що уособлюють державу (відповідно до правил атрибуції поведінки державі), але й із кримінальною відповідальністю осіб, чиї інтереси втілює держава. Посадові особи, які представляють державу і реалізують їі волю, що вилилася у міжнародні злочини, часто виражають по суті злочинну волю та інтереси панівного класу, еліти суспільства (Antypenko, 2012, pp. 186-196).

Важливим внеском В.Антипенка у розвиток концепції КВД $\epsilon$ обгрунтування того, що «інститут кримінальної відповідальності держави створює умови для реалізації одного з головних завдань міжнародного права в цілому- перешкодити самій можливості кримінальної відповідальності народу», будь-якої невиправданої відповідальності народу і невиправданого поширення санкцій на широке населення (Antypenko, 2016a, p. 107). Одночасно, вчений наголошував, що ідею кримінальної відповідальності держави не слід примітизувати, проводячи паралелі 3 кримінальним покаранням індивіда. Призначення кримінальної відповідальності держави передусім полягає у тому, щоб в умовах відповідальності держави, в умовах застосування міжнародноправового примусу до держави, інколи навіть в умовах правомірного тимчасового обмеження суверенітету злочинної держави, визначити фізичних осіб, які вчинили і в інтересах яких вчинено діяння, інкриміноване міжнародною спільнотою певній державі і кваліфіковане міжнародним співтовариством як загрозливе міжнародному миру й безпеці (Antypenko, 2016a, p. 95).

Також, на думку В. Антипенка, призначення КВД полягає у застосуванні кримінальної репресії щодо апарату держуправління, що означає ліквідацію (вилучення), зміну, реформування його ланок i механізмів, а також кримінально-правовий вплив на фізичних осіб, що до нього входять. Але юридична природа такого впливу, що відрізняє його, наприклад, від кримінальної репресії щодо посадових осіб, які представляють державу, полягає в тому, що індивід карається в такому випадку не як фізична особа, а як невід'ємний елемент злочинного «організму» державного управління».

$\overline{\text { (C)Важна К. А., } 2021}$ 


\section{Міжнародні відносини: теоретико-практичні аспекти \\ Випуск 7 (2021) \\ ISSN (print) 2616-745X; ISSN (online) 2616-7794}

Кваліфікаційними критеріями в таких випадках виступають, передусім, критерії, які визначають ступінь злочинної деформації «організму», та індивідуальний внесок у таку деформацію. На думку вченого, «встановлення ознак злочинної за міжнародним правом поведінки для таких осіб $\epsilon$ неможливим поза зв'язком з діяльністю «організму», частиною функції якого вони є» (Antypenko, 2016a, p. 107).

Як вказував В.Антипенко, «зміст кримінального покарання для індивідів, що генерують злочинні діяння держави, носіїв відповідної приватної волі, полягає передусім у вилученні інструментів держапарату, використання яких створює умови, з одного боку, для кримінальних в їх користь дій держави, а 3 іншого, дозволяє переадресовувати авторство таких дій народу (суспільству)» (Antypenko, 2016a, p. 106). У результаті, як вказував вчений, головна ціль досягається, хоча й специфічним чином: «кримінальне покарання держави і антикримінальна щодо неї превенція відбувається через позбавлення можливостей приватних осіб або корпоративних груп використовувати державний апарат в своїх корисливих цілях, надаючи поведінці держави злочинний характер» (Antypenko, 2016a, p. 110).

На думку В.Ф.Антипенка, «інститут кримінальної відповідальності держави покликаний усунути саму цю здатність, схильність державних механізмів трансформуватися і реалізовувати «злу» волю індивідів. Йдеться передусім про усунення (як форми кримінального покарання) тих елементів i органів держави, а можливо і державної машини в цілому, які зазнали кримінальної деформації та які здатні інтегруватися в приватну волю і, будучи перетвореними нею в «живу» суб'єктність, втілювати злочинні інтереси і наміри впливових владних сил» (Antypenko, 2016a, p. 100). Таким чином, кримінальна відповідальність держави, на думку вченого, передбачає конкретну i жорстку кримінально-процесуальну процедуру визначення об’єктів міжнародної кримінальної репресії і її подальшого застосування, орієнтуючись не тільки на злочинних посадових осіб, інститути та органи держави, але передусім на механізми їх трансформації в стан, що результує злочинну поведінку держави в міжнародних взаємодіях (Vazhna, 2017, pp. 84-86).

Виходячи з вищеописаної концепції трансформації волі індивіда у волю держави, професор В.Антипенко у своїй праці «Теорія кримінальної відповідальності держави» висловлювався проти концепції об’єктивної відповідальності держави (Antypenko, 2016а, pp. 88-89). 
Обгрунтовуючи своє бачення сутності КВД, В. Антипенко посилався на дослідження фундаментальної соціологічної науки, яка, за свідченням вченого, стверджує, що «біля витоків соціальної дії завжди стоїть конкретний індивід 3 його інтересами, мотивами, цілями, що втілюються через цю конкретну індивідуальну волю». В. Антипенко наголошував на тому, що у більшості випадків вина $\epsilon$ елементом міжнародного правопорушення (у т. ч. міжнародного злочину), i тому вину потрібно доводити. Проте, встановлення відповідальності держави, на думку вченого, має здійснюватися через встановлення i доведення вини фізичних осіб, які вчинили, або в інтересах яких вчинено міжнародний злочин, що присвоюється державі (Antypenko, 2016a, p. 91, 96).

В. Антипенко вказував, що забезпечення міжнародної безпеки і протидія міжнародним злочинам «все частіше реалізується стихійно». Парадокс, на думку вченого, полягає в тому, що сам цей процес має всі підстави бути кваліфікованим як злочин з боку держав-ініціаторів санкцій. Нерідко в результаті таких «ручних» санкцій закладається основа для конфліктів геополітичного масштабу, хоча самі санкції не завжди $\epsilon$ достатньо ефективними 3 різних причин. В. Антипенко обгрунтовував, що інститут КВД покликаний вивести цю небезпечну тенденцію із зони стихійності, завадити поширенню права сили у міжнародних відносинах (Antypenko, 2016а, pp. 103-104).

у монографії «Теорія кримінальної відповідальності держави» В. Антипенко окреслив і проаналізував актуальну проблему неправомірного використання інформаційно-комунікативних технологій як фактору, що обумовлює відповідальність держави, у т. ч. кримінальну відповідальність держави.

Вказана монографія підсилює позиції наукової школи міжнародної кримінології щодо опори на міжнародно-кримінологічний підхід у міжнародній нормотворчості. Теоретичний матеріал від міжнародної кримінології забезпечив можливість кваліфікації кримінально-правової суб'єктності держави, і отже, обгрунтованість постановки питання про ії міжнародну кримінальну відповідальність. Аргументаційна база монографії В.Ф. Антипенка «Теорія кримінальної відповідальності держави», побудована на положеннях фундаментальної соціології та інших наук, природним порядком утворила основу системної теорії, де системність вказує на її життєздатність (Antypenko, 2016a, summary).

$\overline{\text { (CВажна К. А., } 2021}$ 


\section{Міжнародні відносини: теоретико-практичні аспекти \\ Випуск 7 (2021) \\ ISSN (print) 2616-745X; ISSN (online) 2616-7794}

Під керівництвом професора В.Антипенка на кафедрі міжнародного права Національного авіаційного університету було впроваджено у навчальний процес нові навчальні дисципліни, зокрема «Концепція кримінальної відповідальності держави», яка викладалася на першому курсі магістратури для студентів спеціальності «Міжнародне право».

За ініціативи В.Ф.Антипенка у 2016 р. на базі кафедри міжнародного права Національного авіаційного університету відбулася міжнародна науково-практична конференція на тему «Проблеми відповідальності держави» (Problemy vidpovidal'nosti derzhavy: materialy mizhnarodnoyi naukovopraktychnoyi konferentsiyi, 2016). Окрема секція конференції під назвою «Теорія кримінальної відповідальності держави» (модератором секції виступив В. Антипенко) була присвячена обговоренню різних аспектів доктринальної теорії КВД, а також можливості і доцільності реалізації КВД на практиці. Учений у межах цієї конференції виступив із доповіддю на тему «Теорія кримінальної відповідальності держави» (Antypenko, 2016b), яка стала важливим внеском у сучасний розвиток інституту міжнародноправової відповідальності держав за міжнародні злочини.

У 2018 р. на базі кафедри міжнародного права Національного авіаційного університету відбулися «Наукові читання пам'яті професора Володимира Антипенка»- всеукраїнська науково-практична конференція, присвячена пам'яті В. Антипенка (Naukovi, 2018). На секції «Науковий спадок професора Володимира Федоровича Антипенка обговорювався доробок ученого.

\section{Висновки}

Професор В.Ф. Антипенко зробив вагомий внесок у сучасний розвиток концепції кримінальної відповідальності держави, доповнив і вніс у неї нові наукові ідеї. Дослідження й подальший розвиток концепції КВД стали одним із векторів наукового пошуку у межах наукової школи міжнародної кримінології. Засновником вказаної наукової школи $\epsilon$ В.Ф.Антипенко, а сама наукова школа була сформована i розвивалася на базі кафедри міжнародного права Національного авіаційного університету (Київ, Україна).

Важливим внеском В.Ф.Антипенка у розвиток концепції КВД, серед іншого, стало обгрунтування того, що інститут кримінальної відповідальності держави створює умови для недопущення невиправданого поширення санкцій (у межах реалізації міжнародно-правового примусу та у межах реалізації міжнародно-правової відповідальності держав за міжнародні злочини) на широке населення. На думку В. Ф. Антипенка, зміст кримінального покарання для індивідів, що генерують злочинні діяння держави і $є$ носіями 
відповідної приватної волі, полягає передусім у вилученні інструментів держапарату, використання яких створює умови, 3 одного боку, для кримінальних в їх користь дій держави, а 3 іншого, дозволяє переадресовувати авторство таких дій народу (суспільству). У результаті, як вказує вчений, головна ціль досягається, хоча й специфічним чином: кримінальне покарання держави і антикримінальна щодо неї превенція відбувається через позбавлення можливостей приватних осіб або корпоративних груп використовувати державний апарат у своїх корисливих цілях, надаючи поведінці держави злочинний характер.

\section{References:}

1. Antypenko, V.F. (2007). Teorii mirovogo razvitiya i antiterroristicheskoe pravo. Logika sopryagaemosti [Theories of world development and anti-terrorism law. Logics of conjugacy]. Kyiv.

2. Antypenko, V. F. (2009). Antiterroristicheskaya sistema gosudarstva [State anti-terrorist system]. Kyiv: «Informatsionno-analiticheskoye agenstvo».

3. Antypenko, V.F. (2012). Mezhdunarodnaya kriminologiya: opyt issledovaniya terrorizma [International Criminology: Experience in the Study of Terrorism]. Saarbucken, Deutschland: Lap Lambert Academic Publishing Gmb H\&Co. KG.

4. Antypenko, V.F. (2013). 'Naukova shkola: vzayemovplyv kontseptsiy mizhnarodnoyi kryminolohiyi i kryminal'noyi vidpovidal'nosti derzhavy' [The scientific school: interdependence of concepts of international criminology and criminal responsibility of state]. Derzhava i pravo. Yurydychni i politychni nauky [State and law. Legal and political sciences], no. 62, pp. 332-339.

5. Antypenko, V.F. (2016). Teoriya ugolovnoi otetstvennosti gosudarstva [Theory of State Criminal Responsibility]. Odessa: Feniks.

6. Antypenko, V.F. (2016a). Teoriya ugolovnoi otetstvennosti gosudarstva [Theory of State Criminal Responsibility]. Saarbucken, Deutschland: Lap Lambert Academic Publishing Gmb H\&Co. KG.

7. Antypenko, V.F. (2016b). Teoriya ugolovnoi otetstvennosti gosudarstva [Theory of State Criminal Responsibility]. Problemy vidpovidal'nosti derzhavy: materialy mizhnarodnoyi naukovo-praktychnoyi konferentsiyi. Ukraine, Kyiv, April 8 2016. Odesa: Feniks, pp. 11-32.

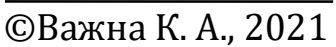




\section{Міжнародні відносини: теоретико-практичні аспекти \\ Випуск 7 (2021) \\ ISSN (print) 2616-745X; ISSN (online) 2616-7794}

8. 'Naukovi chytannya pamyati profesora Volodymyra Antypenka' [Scientific reading of the memory of Professor Volodymyr Antypenko]. (2018). Ukrayinske pravo, [online].

Available at: https://ukrainepravo.com/international_law/public_international_law/naukovichytannya-pam-yati-profesora-volodymyra-antypenka/.

9.'Problemy vidpovidal'nosti derzhavy: materialy mizhnarodnoyi naukovopraktychnoyi konferentsiyi' [Problems of responsibility of the states: materials of the international scientific and practical conference]. (2016). Ukraine, Kyiv, April 82016. Odesa : Feniks.

10. Vazhna, K. A. (2013). Kontseptsiia kryminalnoi vidpovidalnosti derzhavy [Concept of State Criminal Responsibility]. D.Ed. Taras Shevchenko National University of Kyiv.

11. Vazhna, K. A. (2017). Kontseptsiia kryminalnoi vidpovidalnosti derzhavy: mozhlyvist realizatsii v suchasnomu mizhnarodnomu pravi [Concept of State Criminal Responsibility: The Possibility of Realization in Current International Law]. Kyiv: Lira-K Publishing.

12. Vazhna, K. A. (2019). 'Zmist kontseptsiyi kryminal'noyi vidpovidal'nosti derzhavy' [Content of the Concept of State Criminal Responsibility]. Mizhnarodni vidnosyny: teoretyko-praktychni aspekty [International Relations: Theory and Practical Aspects], issue 4, pp. 129-140. DOI: 10.31866/2616-745x.4.2019.177644.

13. Vazhna, K. A. (2019a). 'Poniattia ta kharakterystyka derzhavy yak subiekta mizhnarodnoho publichnoho prava' [The concept and characteristics of a state as a subject of public international law]. Mizhnarodni vidnosyny: teoretyko-praktychni aspekty [International Relations: Theory and Practical Aspects], issue 3, pp. 132-142. DOI: $10.31866 / 2616-745 x .3 .2019 .159113$.

14. Vazhna, K.A., Voloshin, Yu. O. eds. (2018). Volodymyr Fedorovych Antypenko: biobibliohrafichnyy pokazhchyk [Volodymyr Fedorovych Antipenko: biobibliographic index]. Kyiv-Odessa: Phoenix. 


\section{DEVELOPMENT OF THE STATE CRIMINAL RESPONSIBILITY CONCEPT IN THE SCIENTIFIC WORKS OF PROFESSOR VOLODYMYR ANTYPENKO: SCIENTIFIC RESEARCH WITHIN THE SCIENTIFIC SCHOOL OF INTERNATIONAL CRIMINOLOGY}

\section{Vazhna Kateryna}

Ph.D. (International Law),

Kyiv National University of Culture and Arts,

Kyiv, Ukraine

ORCID: 0000-0001-5591-8853

kateryna.vazhna@gmail.com

The contribution of Professor V.F. Antypenko in the current stage of the development of the concept of state criminal responsibility (further - SCR) is demonstrated. It is indicated that Professor V.F. Antipenko made a significant contribution to the current stage of the development of the concept of state criminal responsibility, supplementing and «revitalizing» this concept with new scientific ideas. Research and further development of the concept of SCR has become one of the vectors of scientific research within the scientific school of international criminology. It is indicated that V. F. Antipenko developed new international legal and institutional mechanisms to combat international crimes. Therefore, the research of the contribution of Professor V. F. Antipenko in the development of the concept of SCR is important and can have both theoretical and practical importance in the field of countering international crimes and maintaining international peace and security. The position of V. F. Antypenko regarding the process of transformation of the will of individuals into the will of a state is revealed (among other things), as well as regarding the fact that the institute of state criminal responsibility creates conditions to prevent the possibility itself of any unjustified expansion of sanctions (within the framework of the implementation of international legal coercion and international legal responsibility of states for international crimes) on the population. In V.F.Antypenko's opinion, the aim of the criminal punishment for individuals generating criminal activities of a state and holding the certain private will is first of all to eliminate the instruments of the state apparatus utilization of which on the one hand, creates conditions for criminal actions of a state for the benefit of these individuals and on the other hand, allows readdressing of such actions to the nation (to the society). As a result, according to the scientist, the main objective is achieved, though in a specific way: the criminal punishment of a state and anticriminal

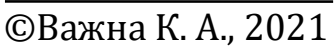


Міжнародні відносини: теоретико-практичні аспекти

Випуск 7 (2021)

ISSN (print) 2616-745X; ISSN (online) 2616-7794

prevention regarding it take place through the denying the individuals or corporate entities the possibility to use the state apparatus in their selfish objectives, giving the behaviour of a state the criminal character.

Key words: Professor Volodymyr Fedorovych Antypenko; the concept of state criminal responsibility; international crime; international criminal law; international responsibility; scientific school of international criminology. 


\title{
РАЗВИТИЕ КОНЦЕПЦИИ УГОЛОВНОЙ ОТВЕТСТВЕННОСТИ ГОСУДАРСТВА В НАУЧНЫХ ТРУДАХ ПРОФЕССОРА ВЛАДИМИРА АНТИПЕНКА: НАУЧНЫЙ ПОИСК В РАМКАХ НАУЧНОЙ ШКОЛЫ МЕЖДУНАРОДНОЙ КРИМИНОЛОГИИ
}

\author{
Важна Катерина Анатольевна \\ кандидат юридических наук, \\ Киевский национальный университет культуры и искусств, \\ 2. Киев, Украина \\ ORCID: 0000-0001-5591-8853 \\ kateryna.vazhna@gmail.com
}

Раскрывается вклад профессора В.Ф.Антипенка в современный этап развития концепции уголовной ответственности государства (далее- УОГ). Указывается, он сделал весомый вклад в современное развитие концепции уголовной ответственности государства, дополнив и «оживив» данную концепцию новыми научными идеями. Исследования и дальнейшее развитие концепции УОГ стали одним из векторов научного поиска в рамках научной школы международной криминологии. Указывается, что В.Ф. Антипенко разрабатывал новые международные нормативно-правовые и институциональные механизмы борьбы с международными преступлениями. Поэтому изучение вклада профессора В.Ф. Антипенка в развитие концепции УОГ является важным и может иметь как теоретическое, так и важное практическое значение в сфере противодействия международным преступлениям и поддержания международного мира и безопасности. Среди прочего, в статье раскрывается позиция В.Ф.Антипенка о процессе трансформации воли индивидов в волю государства, а также о том, что институт уголовной ответственности государства создает условия для недопущения неоправданного распространения санкций (в рамках реализации международно-правового принуждения и в рамках реализации международноправовой ответственности государств за международные преступления) на широкое население. По мнению В.Ф. Антипенка, содержание уголовного наказания для индивидов, которые генерируют преступные деяния государства и являются носителями соответствующей частной воли, заключается прежде всего в изъятии инструментов госаппарата, использование которых создает условия, с одной стороны, для уголовных

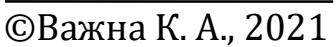


в их пользу действий государства, а с другой, позволяет переадресовывать авторство таких действий народу (обществу). В результате, как указывает ученый, главная цель достигается, хотя и специфическим образом: уголовное наказание государства и антикриминальная в отношении него превенция происходит путем лишения возможностей частных лиц или корпоративных групп использовать государственный аппарат в своих корыстных целях, придавая поведению государства преступный характер.

Ключевые слова: профессор Владимир Федорович Антипенко; концепция уголовной ответственности государства; международное преступление; международное уголовное право; международная ответственность; научная школа международной криминологии. 